\title{
Pelatihan Bahasa Inggris Bagi Pokdarwis dalam Rangka Mendukung Pengembangan Desa Wisata di Desa Sukajadi, Bogor
}

\author{
Riani Prihatini Ishak ${ }^{1)}$, Maidar Simanihuruk ${ }^{2)}$ \\ 1) Sekolah Tinggi Pariwisata Bogor, rianipishak@stpbogor.ac.id \\ 2) Sekolah Tinggi Pariwisata Bogor, meydar_bj@yahoo.co.id
}

\begin{abstract}
ABSTRAK
Adanya peningkatan minat wisatawan baik lokal maupun mancanegara terhadap desa wisata perlu dibarengi dengan adanya peningkatan sumber daya manusia dalam hal berkomunikasi, khususnya komunikasi dalam Bahasa Inggris sebagai bahasa yang paling banyak digunakan sebagai penghubung antara wisatawan dengan para pelaku wisata. Masyarakat sebagai tuan rumah di desa wisata harus diperlengkapi dengan kemampuan berbahasa Inggris yang baik. Tujuan dari kegiatan Pengabdian Kepada Masyarakat (PKM) ini adalah memberikan pelatihan untuk membantu kelompok sadar wisata (Pokdarwis) Desa Sukajadi di Kecamatan Tamansari, Bogor dalam meningkatkan kemampuan komunikasi Bahasa Inggris khusus untuk wisata. Berdasarkan wawancara yang dilakukan sebelum program ini dimulai, masyarakat Desa Sukajadi secara keseluruhan masih belum memiliki kemampuan yang baik dalam menggunakan Bahasa Inggris untuk kepentingan wisata. Untuk memecahkan masalah tersebut salah satu solusi tercepat adalah melalui metode pelatihan atau kursus menggunakan Bahasa Inggris praktis, yakni dengan berlatih/praktek langsung keterampilan menggunakan Bahasa Inggris dalam berinteraksi dengan tamu, menjelaskan potensi wisata alam atau pertanian, menjelaskan akomodasi, dan fasilitas pelengkap pariwisata. Secara umum berdasarkan analisis hasil kuesioner yang diberikan kepada peserta pelatihan, tidak ada kendala maupun kesulitan yang dihadapi dalam mengikuti pelatihan ini. Pokdarwis dan kepala desa merasa sangat terbantu dengan adanya pelatihan ini dan sebagian besar peserta dapat memahami dengan baik semua materi yang diberikan. Peserta juga menyadari akan pentingnya memperdalam kemampuan berbahasa Inggris, terutama keterampilan berbicara (speaking skill).
\end{abstract}

Kata-kata Kunci: Pelatihan Bahasa Inggris, Pokdarwis, Desa Wisata, Desa Sukajadi Bogor

\begin{abstract}
The interest of both local and foreign tourists to village tourism is increasing nowadays. Thus it needs to be in line with the development in human resources in terms of communication skill, especially communication in English, since English is known as the language most widely used by and between tourists and other tourism parties. Village community as hosts in their village must be equipped with good English skills. The purpose of this Community Service (PKM) activity is to provide language training in order to help the Wisata Awareness Group (Pokdarwis) in Sukajadi Village, Tamansari District, Bogor improving their English communication skills in specific for tourism purpose. Based on interviews conducted before the program started, the community in Sukajadi Village in general still do not have good skills in using English for tourism purposes. The method to solve this problem, one of the fastest solutions is by giving training or courses on how to use English by practicing directly using English in interacting with guests, explaining the potential for natural or agricultural tourism, explaining accommodation and tourism facilities in their village. In general, based on the analysis of the results of the questionnaire given to the training participants, there were difficulties encountered in participating this training. The Pokdarwis and the village head officer were thankful and helped by this training occasion and most of the participants were able to understand the material that had been given quite well. Participants also realized the importance of sharpening their English skills, especially speaking skill.
\end{abstract}

Keywords: English Training, Pokdarwis, Tourism Village, Sukajadi Village Bogor.

\section{PENDAHULUAN}

Kompetensi Bahasa Inggris hendaknya harus dimiliki oleh setiap sumber daya manusia (SDM) dari setiap daerah pariwisata, utamanya SDM di Desa Sukajadi, Bogor. Kompetensi Bahasa Inggris merupakan salah satu faktor penentu pelayanan yang baik bagi 
wisatawan. Berdasarkan wawancara dengan Ketua Pokdarwis Desa Sukajadi, mereka harus mempersiapkan diri untuk menerima wisatawan asing ke desanya. Bahasa Inggris tentu memiliki peranan penting dalam dunia pariwisata dan sudah sangat lazim digunakan dalam industri ini. Penggunaan Bahasa Inggris di industri pariwisata memudahkan komunikasi antar pelaku pariwisata dan para wisatawan dari segala penjuru dunia.

Pariwisata adalah salah satu sektor yang mendapat perhatian lebih dan prioritas dari pemerintah karena sektor pariwisata mengalami perkembangan yang sangat pesat. Desa Sukajadi merupakan salah satu desa yang terletak di Kecamatan Tamansari, Kabupaten Bogor yang mempunyai potensi Sumber Daya Alam (SDA) yang indah dan masih terjaga keasriannya. Desa ini disebut sebagai desa wisata karena dinilai layak oleh pemerintah setempat dan sekitarnya memiliki cukup banyak lokasi maupun atraksi wisata yang unik, Dalam rangka pengembangan desa diperlukan pembinaan terhadap warga lokal yang mengelola desa tersebut baik dalam perencanaan maupun pengembangan. Salah satu dari keterampilan yang perlu dimiliki oleh masyarakat agar mampu bersaing ialah kemampuan dalam Bahasa Inggris. Sayangnya, kemampuan ataupun keterampilan masyarakat Indonesia masih dinilai rendah dibandingkan negara-negara lain Asia Tenggara lainnya (Iriance, 2018). Melihat dari data tersebut, maka sangat disayangkan jika Indonesia dengan anugerah Tuhan atas keindahan alam yang dimilikinya tidak dapat memanfaatkan atau mengembangkannya dengan baik.

Desa Sukajadi merupakan desa yang terletak di Ciapus, Ciomas yang mempunyai potensi sumber daya alam yang melimpah dan masih sejuk dan segar. Di sisi lain masyarakat Desa Sukajadi mayoritasnya adalah petani sayuran. Hal ini menandakan bahwa SDA dan kawasan Desa Sukajadi memiliki kondisi alam yang sangat baik. Desa wisata adalah suatu bentuk integrasi antara atraksi, akomodasi, dan fasilitas pendukung yang disajikan dalam suatu struktur kehidupan masyarakat yang menyatu dengan tata cara tradisi yang berlaku. Selain itu, desa wisata juga merupakan pariwisata yang terdiri dari keseluruhan pengalaman pedesaan, atraksi alam, tradisi, unsur-unsur yang unik yang secara keseluruhan dapat menarik wisatawan (Nuryanti, 2015).

Dalam memberikan pelayanan yang baik kepada para wisatawan asing yang datang berkunjung ke Desa Sukajadi, masalah utama yang memerlukan penanganan dengan segera adalah masalah SDM. Masalah ini dapat diatasi dengan menambah pendidikan non formal berupa pelatihan penggunaan Bahasa Inggris komunikatif yang sesuai dengan konteks pariwisata dengan tujuan untuk meningkatkan kompetensi komunikasi peserta dengan pemberian materi pembelajaran kontekstual yang mengaitkan dengan kebutuhan riil di dalam kehidupan sehari-hari (Johnson, 2002). Hasil penelitian oleh Irfan dan Suryani (2017) menegaskan bahwa salah satu yang berperan utama dalam keberhasilan pariwisata adalah partisipasi masyarakat dan dukungan potensi yang dimiliki oleh desa. PKM kali ini 
dilaksanakan oleh dosen dan mahasiswa dengan sasaran anggota Kelompok Sadar Wisata (Pokdarwis) dengan tujuan meningkatkan kesadaran terhadap pentingnya Bahasa Inggris bagi kepariwisataan sekaligus mengenalkan penerapannya kepada masyarakat desa setempat. Setelah adanya kegiatan ini diharapkan materi yang disampaikan bermanfaat dan dapat dikembangkan sendiri oleh anggota Pokdarwis dan perangkat Desa Sukajadi demi kemajuan desa wisata tersebut.

\section{METODE PELAKSANAAN}

Pelatihan Bahasa Inggris merupakan salah satu bentuk dari Kegiatan Pengabdian kepada Masyarakat (PKM) yang dilaksanakan oleh dosen dan mahasiswa Diploma 4 Perhotelan Sekolah Tinggi Pariwisata (STP) Bogor. Dalam pelaksanaannya kegiatan pelatihan Bahasa Inggris untuk Pokdarwis Desa Sukajadi, digunakan 3 (tiga) metode yaitu (1) pembagian modul atau handbook yang berisi materi presentasi yang akan disampaikan kepada masyarakat yang hadir dalam kegiatan, (2) presentasi materi oleh dosen dan mahasiswa, dan (3) praktek percakapan sederhana antara peserta dengan dosen dan mahasiswa. Foto-foto kegiatan dapat dilihat pada Gambar 1 dan Gambar 2.
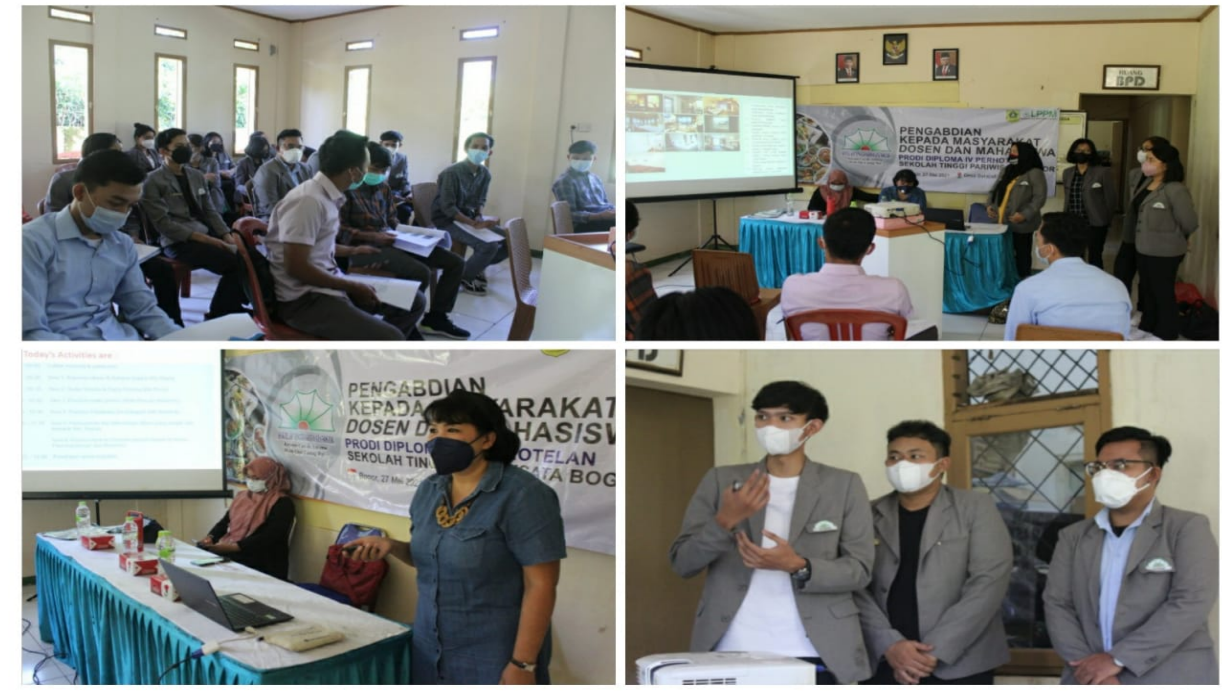

Gambar 1.

Presentasi Materi oleh Dosen dan Mahasiswa

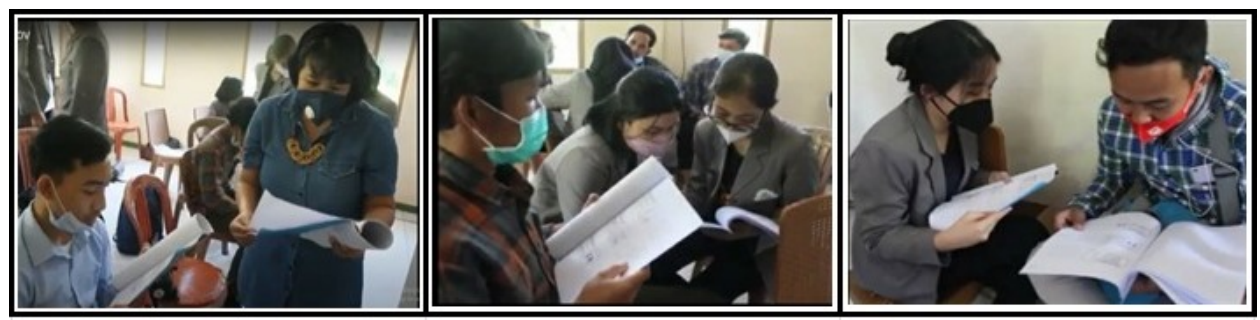

Gambar 2.

Praktek Percakapan Antara Peserta dengan Dosen dan Mahasiswa 
Keseluruhan materi berkaitan dengan pemahaman mengapa Bahasa Inggris sangat penting bagi pelaku wisata serta poin-poin apa yang harus dikuasai dalam Bahasa Inggris. Mahasiswa yang menyampaikan materi pelatihan sebelumnya telah mendapatkan pelatihan (training of trainer) oleh dosen pengampu Bahasa Inggris di STP Bogor.

Pelatihan ini dilakukan secara tatap muka dengan mematuhi protokol kesehatan yang berlaku dan dilaksanakan dalam satu hari pada tanggal 27 Mei 2021 karena masih dalam situasi Pandemi Covid-19 dimana kebijakan Pembatasan Sosial Berskala Besar (PSBB) sedang diterapkan. Dengan pemberlakuan PSBB ini maka peserta pelatihan yang diikutkan pada pelatihan ini memang yang terpilih yaitu sebanyak 9 orang dimana mereka adalah tim inti Pokdarwis setempat yang aktif dalam pengembangan wisata di desa Sukajadi.

\section{HASIL DAN PEMBAHASAN}

\subsection{Desa Wisata dan Desa Sukajadi}

Desa wisata merupakan kawasan pedesaan yang menawarkan keseluruhan suasana yang mencerminkan keaslian pedesaan, baik dari kehidupan sosial ekonomi, sosial budaya, adat istiadat, keseharian, memiliki arsitektur bangunan dan struktur tata ruang yang khas, atau kegiatan ekonomi yang unik dan menarik serta memiliki potensi untuk dikembangkannya berbagai komponen kepariwisataan seperti atraksi, akomodasi, makanan minuman, dan kebutuhan wisata lainnya (Hadiwijoyo, 2012).

Kepala Desa Sukajadi menyambut baik adanya kegiatan PKM dosen dan mahasiswa STP Bogor di Desa Sukajadi, karena menyadari akan pentingnya kemampuan berbahasa asing bagi para remaja di desanya untuk bisa mengembangkan Desa Sukajadi menjadi desa yang diminati oleh wisatawan asing. Banyak alasan yang bisa diberikan bagi pelancong untuk melakukan perjalanan wisata ke Desa Sukajadi, diantaranya adalah keramahtamahan masyarakat Desa Sukajadi, suhu udara di desa ini sangat sejuk dan segar serta memiliki pemandangan pegunungan yang indah, dikelilingi atraksi alam yang menarik seperti air terjun dan hutan pinus. Para wisatawan dapat melihat keseharian masyarakat desa dan bersawah bersama petani. Berkemah di Bumi Perkemahan Hutan Pinus Kali Mati dan menikmati matahari terbit / atau terbenam, staycation di homestay-homestay yang ada di Sukajadi juga merupakan pilihan yang menarik, berenang atau bermain air di Curug Nangka, mengunjungi Pura Parahyangan Agung dan berfoto bersama dengan latar belakang Gunung Salak, bersepeda atau berjalan-jalan di tepian sawah. Peta lokasi terlampir (Lampiran 1).

Pengembangan desa wisata merupakan suatu proses yang menekankan cara untuk mengembangkan atau memajukan desa wisata. Secara lebih spesifik, pengembangan desa wisata diartikan sebagai usaha-usaha untuk melengkapi dan meningkatkan fasilitas wisata 
untuk memenuhi kebutuhan wisatawan. Pengembangan desa wisata adalah suatu proses bagaimana sebuah desa dapat berkembang dan sebagai pusat wisata yang memiliki unsur hiburan dan pendidikan. Pembangunan sektor pariwisata sangat potensial untuk mewujudkan kesejahteraan masyarakat dengan melibatkan peran aktif masyarakat dalam pengelolaannya (Marpaung, 2002).

Berdasarkan jenis pariwisata yang diungkapkan oleh (Suwena \& Widyatmaja, 2017) dapat disimpulkan bahwa jenis pariwisata yang dapat dilakukan oleh wisatawan di Desa Sukajadi adalah vacational dan sport tourism, yaitu jenis pariwisata yang membuat para wisatawan dapat berekreasi di suatu tempat dan menikmati olahraga yaitu water sport. Banyak desa yang memiliki keunikan tersendiri, termasuk potensi alam, budaya, dan tradisi dapat memperenalkannya kepada wisatawan melalui bisnis pariwisata yang dikenal dengan nama village-based tourism. Menurut Irfan \& Suryani (2017), village based tourism adalah suatu bentuk integrasi antara atraksi, akomodasi dan fasilitas pendukung yang disajikan dalam struktur kehidupan masyarakat yang menyatu dengan ordonansi dan tradisi. Jadi, konsep village-based tourism adalah upaya untuk memberdayakan masyarakat pedesaan. Ini mengacu pada sebuah desa dengan semua sumber daya lokal yang dimilikinya, mengelola, dan menyajikan kepada wisatawan.

Menurut Hamzah \& Irfan (2018) dan Ratminingsih, Budasi, Adnyani, Suniyasih, \& Wulandari (2020), ada 3 (tiga) komponen utama yang diperlukan sebagai landasan dalam pengembangan village-based tourism yaitu (1) infrastruktur (jalan, listrik, dan lainnya); (2) bahan (sumber daya alam, struktur publik dan swasta, dan lainnya); dan (3) komponen material (kapasitas masyarakat lokal untuk mengambil keuntungan dari sumber daya yang ada, kondisi lingkungan politik dan sosial budaya. Selanjutnya (Damanik 2013) menyatakan beberapa tipologi village-based tourism yang ada dalam berbagai referensi adalah sebagai berikut (1) keunikan desa wisata berbasis SDA sebagai wisata utama; (2) sumber daya budaya lokal desa berbasis keunikan sebagai daya tarik wisata; (3) kegiatan / karya kreatif desa wisata berbasis keunikan sebagai daya tarik wisata; dan (4) keunikan SDA, sumber daya budaya lokal, dan kegiatan kampung wisata sebagai daya tarik wisata. Berdasarkan tipologinya, Desa Sukajadi digolongkan dalam tipe pertama yaitu village based tourism, dimana yang dapat dikembangkan di desa ini adalah wisata alam yang berupa air terjun (waterfall), trekking untuk melihat pemandangan alam seperti: rice field, pine forest camping ground, temple yang dikombinasikan dengan beberapa keunikan lain diantaranya taman anggrek, taman kupu-kupu, dan rumah makan bernuansa alam pedesaan. Beberapa destinasi unggulan Desa Sukajadi adalah sebagaimana terlihat pada Lampiran 2. 


\subsection{Pokdarwis}

Pokdarwis merupakan salah satu program yang dicetuskan untuk meningkatkan industri pariwisata suatu daerah di Indonesia. Pokdarwis adalah salah satu komponen masyarakat yang sadar akan potensi pariwisata dan berkontribusi dalam mengembangkan kepariwisataan (Rahim, 2012). Pokdarwis adalah kelompok masayarakat yang memiliki kegiatan menjaga dan megembangkan wisata suatu daerah. Jadi, pokdarwis merupakan kegiatan pemberdayaan masyarakat untuk memajukkan daerah sendiri khususnya dalam bidang kepariwisataan. Peranan dari Pokdarwis dalam pengembangan potensi pariwisata (Suryawan, 2016) yaitu (1) memperkenalkan, mempromosikan, melestarikan, dan memanfaatkan potensi pariwisata; (2) mengelola pariwisata; (3) memberikan pengetahuan dan keterampilan kepada anggota dan masyarakat mengenai kepariwisataan; dan (4) menjalin kerjasama dengan pemegang saham atau investor dan lembaga lain yang bergerak di bidang kepariwisataan. Berdasarkan uraian di atas Pokdarwis adalah sekelompok masyarakat yang memiliki kesadaran terhadap potensi yang dimiliki oleh suatu desa dalam usaha mengembangkan pariwisata. Perkembangan industri pariwisata harus sejalan dengan perkembangan kualitas sumber daya manusia, Salah satu kompetensi yang harus dimiliki adalah berkomunikasi dalam bahasa Inggris yang memadai untuk dapat menjalin kerjasama dengan berbagai pihak.

Banyak wisatawan lokal maupun mancanegara yang mencari destinasi wisata alam yang menawarkan kesan dan memberikan pengalaman berwisata yang berbeda dan unik di Indonesia, salah satunya adalah berwisata ke desa-desa. Pokdarwis Desa Sukajadi menyadari peran dan fungsi nya sangatlah penting bagi terciptanya desa wisata yang mengesankan bagi turis lokal maupun asing.

\subsection{Peran Bahasa Inggris bagi Pariwisata}

Joseph, Munghate, \& Kurkheda (2012) dan Damayanti (2019) menyatakan ada 6 (enam) peran penting Bahasa Inggris dalam dunia pariwisata, yaitu:

1. Peran Komunikatif/Interaktif.

Bahasa Inggris merupakan media komunikasi antara pelaku wisata dengan wisatawan dan antar wisatawan. Bahasa asli tidak dapat lagi digunakan ketika orang dari berbagai negara datang mengunjungi suatu destinasi pariwisata karena wisatawan tidak memahami bahasa tersebut begitupun sebaliknya.

2. Peran Fungsional.

Peran ini membantu wisatawan dan masyarakat lokal dalam memperoleh informasi tertentu, meminta bantuan, dan fungsi lain yang dibutuhkan dalam kegiatan pariwisata. 
3. Peran Integratif.

Seperti diketahui pula kegiatan pariwisata yang melibatkan banyak orang dari berbagai negara, adat istiadat, budaya, ras, dan minat. Bahasa Inggris berperan dalam mengintegrasikan semua orang tanpa memandang latar belakang mereka.

4. Peran Lingua-Franca.

Bahasa Inggris adalah jembatan bagi wisatawan dan operator tur. Lingua-Franca dapat diartikan sebagai bahasa pengantar atau pergaulan bagi orang-orang yang tinggal di lingkungan multibahasa.

5. Peran Pembina Relasi.

Dalam dunia pariwisata, Bahasa Inggris memungkinkan wisatawan untuk berpartisipasi dalam aktivitas atau aktivitas masyarakat setempat. Hal ini dikarenakan wisatawan dapat terlibat dalam dialog dan diskusi dengan komunitas lain menggunakan media berbahasa Inggris.

6. Peran Ekonomi/Bisnis.

Peran bahasa Inggris sangat besar dalam hal bisnis dan ekonomi. Bahasa Inggris adalah bahasa pengantar dalam bisnis, terutama dalam bisnis pariwisata.

\section{3. Pentingnya Kemampuan Bahasa Inggris untuk Pokdarwis Desa Wisata Sukajadi}

Materi yang disepakati untuk disampaikan pada pembinaan kali ini adalah Why English is Important for Tourism yang dibawakan oleh dosen, Tourism Awareness \& Seven Tourist Charms (Sapta Pesona) yang dibawakan oleh dosen. Adapun materi tentang Greeting \& Introducing Yourself, Tourism Vocabulary, Homestay Reservation, Tourist Welcoming, dan Tour Guide Dialogue dibawakan dan dicontohkan oleh mahasiswa.

Setelah melakukan proses pembinaan dan praktek, masyarakat diminta untuk mengisi angket. Angket ini digunakan sebagai alat pengumpulan data dalam mengetahui pemahaman peserta dan tanggapannya menurut kegiatan pembinaan ini. Angket yang diberikan mencakup pertanyaan (1) latar belakang pendidikan Bahasa Inggris peserta; (2) pemahaman terhadap topik - topik yang diberikan; (3) penyampaian materi secara keseluruhan; (4) kebutuhan Bahasa Inggris kedepannya. Berikut adalah hasil dari angket yang telah diisi oleh masyarakat beserta pembahasannya.

Peserta yang mendapat pelatihan menilai tentang sangat pentingnya mempelajari Bahasa Inggris dimanapun berada dan dengan berbagai aspek apa saja, terlihat dari hasil kuesioner yang dilakukan pada 9 orang, diperoleh hasil yaitu 5 orang menyatakan sangat penting dan 4 orang menyatakan penting. Sebagian besar peserta pada dasarnya sudah pernah belajar Bahasa Inggris ketika mereka menempuh pendidikan di sekolah menengah, jadi sudah cukup lama rata-rata sudah diatas 10 tahun yang lalu. 
Semua peserta menilai bahwa pemahaman terhadap Bahasa Inggris mereka saat ini masih sangat kurang, dimana yang tersulit adalah keterampilan berbicara (speaking skill) terutama untuk keperluan menjelaskan dan presentasi atau public speaking dibandingkan dengan 3 keterampilan lainnya yaitu mendengarkan, membaca dan menulis (listening, reading dan writing skills). Dalam kesehariannya lebih dari $50 \%$ peserta sering menemukan teks atau artikel dalam Bahasa Inggris, mereka juga merasa kesulitan dalam memahami tata Bahasa Inggris itu yang memiliki beragam stuktur kata dan kalimat. Karena itu peserta menganggap bahwa kegiatan pelatihan Bahasa Inggris untuk Pokdarwis kali ini sangatlah tepat sasaran dan cocok sekali dengan kebutuhan dan keadaan Desa Wisata Sukajadi.

Tingkat pemahaman peserta terhadap materi-materi yang diberikan dapat dilihat pada Tabel 1. Berdasarkan tabel tersebut dapat diketahui bahwa seluruh peserta tidak mengalami kesulitan dalam mempelajari materi yang diberikan oleh pemateri baik dosen maupun mahasiswa.

Tabel 1. Tingkat Pemahaman Peserta terhadap Materi Pelatihan

\begin{tabular}{|c|l|l|c|c|c|c|}
\hline No. & \multicolumn{1}{|c|}{ Indikator } & Pemateri & $\begin{array}{c}\text { Sangat } \\
\text { paham }\end{array}$ & Paham & $\begin{array}{c}\text { Kurang } \\
\text { paham }\end{array}$ & $\begin{array}{c}\text { Tidak } \\
\text { paham }\end{array}$ \\
\hline 1 & $\begin{array}{l}\text { Topik Kepariwisataan \& Bahasa } \\
\text { Inggris }\end{array}$ & Dosen & $22 \%$ & $78 \%$ & 0 & 0 \\
\hline 2 & $\begin{array}{l}\text { Topik Sadar Wisata \& Sapta Pesona } \\
\text { versi Bahasa Inggris }\end{array}$ & Dosen & $22 \%$ & $67 \%$ & $11 \%$ & 0 \\
\hline 3 & $\begin{array}{l}\text { Topik Salam dan Perkenalan Diri } \\
\text { (Greeting \& Introducing yourself })\end{array}$ & Mahasiswa & $11 \%$ & $89 \%$ & 0 & 0 \\
\hline 4 & $\begin{array}{l}\text { Topik Kosakata terkait Homestay } \\
\text { dan Pemandu Wisata } \\
\text { (Homestay \& Tourist Guide } \\
\text { Vocabulary ) }\end{array}$ & Mahasiswa & $11 \%$ & $78 \%$ & $11 \%$ & 0 \\
\hline 5 & $\begin{array}{l}\text { Topik Menyambut wisatawan dan } \\
\text { pemesanan homestay } \\
\text { (Welcoming wisatawan \& Homestay } \\
\text { Reservation ) }\end{array}$ & Mahasiswa & $11 \%$ & $67 \%$ & $22 \%$ & 0 \\
\hline
\end{tabular}

Sumber: Data Primer

Dalam hal penyampaian materi secara keseluruhan unsur-unsur yang ditanyakan kepada peserta adalah perihal (1) kejelasan materi; (2) interaksi dengan peserta; (3) penyampaian materi oleh dosen dan (4) penyampaian materi oleh mahasiswa. Secara keseluruhan lebih dari $75 \%$ peserta menyatakan bahwa penyampaian materi sudah baik, dan sebagian kecil menyatakan penyampaiannya adalah sudah sangat baik.

Selanjutnya indikator- indikator terhadap kebutuhan Bahasa Inggris kepada peserta ditanyakan antara lain seberapa penting peran Bahasa Inggris bagi pekerjaan atau kegiatan pokdarwis, keterampilan yang paling mana yang paling diperlukan, teknik belajar Bahasa Inggris yang menarik menurut peserta, dan keuntungan yang diperoleh setelah mendapat 
pelatihan Bahasa Inggris. Semua peserta menilai bahwa mempersiapkan kemampuan berbahasa Inggris untuk pekerjaan atau kegiatan kepariwisataan yang akan datang sangatlah penting. Selain itu peserta berpendapat bahwa Bahasa Inggris sangat penting juga untuk relasi bisnis, melakukan percakapan, mendengar dan berbicara dengan wisatawan, juga mempermudah komunikasi ketika melayani turis asing.

Menurut pendapat seluruh peserta pelatihan keterampilan yang paling perlu dikuasai terlebih dahulu adalah berbicara untuk menunjang peran mereka sebagai pokdarwis apabila bertemu wisatawan asing. Adapun teknik belajar Bahasa Inggris yang menarik adalah dengan praktik langsung di lapangan menurut sebagian besar peserta, teknik menarik lainnya adalah melalui game atau permainan. Peserta sangat menyadari akan adanya keuntungan yang akan Anda peroleh setelah menjalani pelatihan Bahasa Inggris mereka akan lebih percaya diri dalam menggunakan Bahasa Inggris dalam keseharian mereka sebagai pokdarwis di desanya.

\section{KESIMPULAN}

Berdasarkan hasil dan pembahasan di atas dapat disimpulkan bahwa Bahasa Inggris sangat penting dalam proses komunikasi yang terjadi di industri pariwisata baik itu untuk kepentingan komunikasi antara wisatawan dan pelaku wisata maupun komunikasi dalam hal bisnis. Bahasa Inggris juga sangat diperlukan oleh pelaku wisata di Desa Sukajadi, Kecamatan Tamansari untuk menghadapi kedatangan tamu wisatawan asing di waktu yang akan datang seiring dengan berkembangnya potensi pariwisata di Indonesia. Kegiatan ini dihadiri oleh 9 orang peserta yang seluruhnya merupakan anggota kelompok sadar wisata. Seluruh peserta mengikuti kegiatan dari awal mulai hingga selesai. Selama kegiatan pembinaan berlangsung, para anggota kelompok sadar wisata juga berkonsentrasi penuh kepada materi yang disampaikan dan sangat kooperatif saat diminta tolong untuk berpartisipasi disetiap bagiannya baik itu saat penyampaian materi, prosesi tanya jawab, dan juga kuis.

Manfaat dari kegiatan pembinaan ini dirasa belum optimal kerena keterbatasan waktu pelatihan yang sangat singkat dan peserta masih merasa sangat perlu meningkatkan kemampuan dan penerapan dalam berbahasa Inggris untuk kegiatan kepariwisataan di desanya. Pembelajaran yang disarankan bagi kelompok sadar wisata dalam belajar Bahasa Inggris dapat melalui latihan secara berkala, baik dari media tertulis (kamus, buku pelajaran, dII) maupun media digital (YouTube, podcast, music, dan lain lain). Penguasaan Bahasa Inggris dan pengaplikasiannya merupakan suatu hal yang penting bagi pelaku usaha wisata di Desa Sukajadi, oleh karena itu perlu adanya pelatihan yang lebih intensif dan rutin secara berkala. 


\section{UCAPAN TERIMA KASIH}

Kegiatan PKM ini dapat terlaksana dengan lancar berkat adanya kerjasama dan partisipasi yang baik dari semua pihak, karena itu kami ucapkan terima kasih kepada Kepala Desa Sukajadi beserta jajarannya, Ketua Pelaku Sadar Wisata (Pokdarwis) Desa Sukajadi, Tim LPPM Sekolah Tinggi Pariwisata Bogor dan Mahasiswa Program Studi D4 Perhotelan Sekolah Tinggi Pariwisata Bogor yang namanya tercantum dalam Lampiran 3, yang telah ikut melakukan presentasi dan praktek percakapan sederhana antara peserta dengan dosen dan mahasiswa.

\section{REFERENSI}

Damanik, P. J. 2013. Pariwisata Indonesia antara Peluang dan Tantangan. Yogyakarta: Pustaka Pelajar.

Damayanti, L.S. 2019. Peranan Keterampilan Berbahasa Inggris dalam Industri Pariwisata." Journey (Politeknik Internasional Bali), II (1): 71-82.

Hadiwijoyo, S.S. 2012. Perencanaan Pariwisata Perdesaan Berbasis Masyarakat (Sebuah Pendekatan Konsep). Yogyakarta: Graha IImu.

Hamzah, A. S., Irfan, M. 2018. Law Enforcement of Constitutional Court Decision NO. 69/PUU-XII/2015 (Mixed Marriage Issue Without Marriage Agreement)." Jurnal Notariil (Universitas Warmadewa, Denpasar, Bali), III(1): 1-12.

Irfan, M., Suryani, A. 2017. Local Wisdom Based Tourist Village Organization in Lombok Tourist Area. International Journal of English Literature and Social Sciences (IJELS), II (5): 73-82. Diunduh dari https://www.neliti.com/publications/239220/local-wisdombased-tourist-village-organization-in-lombok-tourist-area

Iriance, I. 2018. Bahasa Inggris Sebagai Bahasa Lingua Franca dan Posisi Kemampuan Bahasa Inggris Masyarakat Indonesia Diantara Anggota MEA. Prosiding Industrial Research Workshop and National Seminar. IRWNS. Diunduh dari https://jurnal.polban.ac.id/ojs-3.1.2/proceeding/article/view/1149

Johnson, E. B. 2002. Contextual Teaching \& Learning, What it is and why it's here to stay. California: Corwin Press, Inc.

Joseph, T.C, Munghate, R.G., Kurkheda. 2012. Role of English in Travel, Tourism and Hospitality Industry The Multi-faceted Role of English. Sanjay Thakre, Shri. Sahitry Kendra, Nagpur, 220-227. Diunduh dari https://www.researchgate.net/publication/330555468_Role_of_English_in_Travel_To urism_Hospitality_Industry

Marpaung, H. 2002. Pengantar Pariwisata. Bandung: Alfabeta.

Nuryanti, W. 2015. Concept, Perspective and Challenges. Laporan Konferensi Internasional Mengenai Pariwisata Budaya. Yogyakarta: Universitas Gajah Mada.

Rahim, F. 2012. Pedoman Kelompok Sadar Wisata. Jakarta: Kementerian Pariwisata dan Ekonomi Kreatif. 
Ratminingsih, N.M, Budasi, I,G., Adnyani, N.K.P., Suniyasih, N.M, \& Wulandari, P.R. 2020. Pelatihan Bahasa Inggris bagi Pokdarwis Desa Ambengan Kecamatan Sukasada dalam Rangka Mendukung Village-Based Tourism. Singaraja, Bali: Fakultas Bahasa dan Seni UNDIKSHA: 384-395.

Suryawan, A. 2016. Peran Kelompok Sadar Wisata (Pokdarwis) Sendang Arum Dalam Pengembangan Potensi Pariwisata (Studi Kasus Di Desa Wisata Tlahab Kecamatan Kledung Kabupaten Temanggung). Yogyakarta: Lumbung Pustaka Universitas Negeri Yogyakarta.

Suwena, I. K., Widyatmaja, I.G.N. 2017. Pengetahuan Dasar IImu Pariwisata. Edisi Revisi. Denpasar, Bali: Pustaka Larasan.

\section{LAMPIRAN}

Lampiran 1.

Peta Wilayah

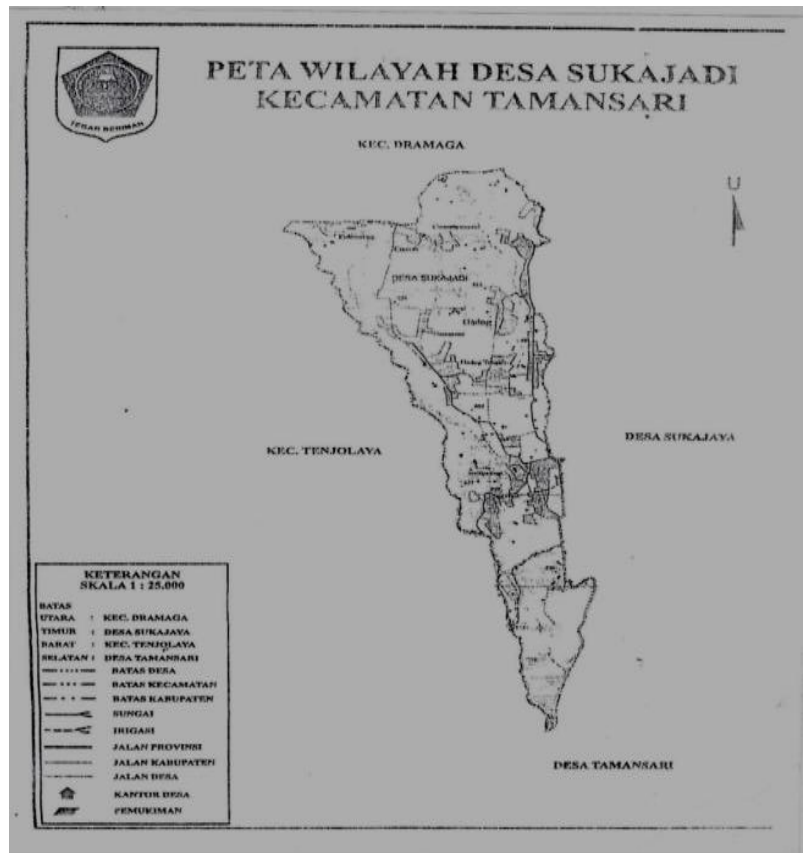


Lampiran 2.

Foto Destinasi Wisata di Desa Sukajadi
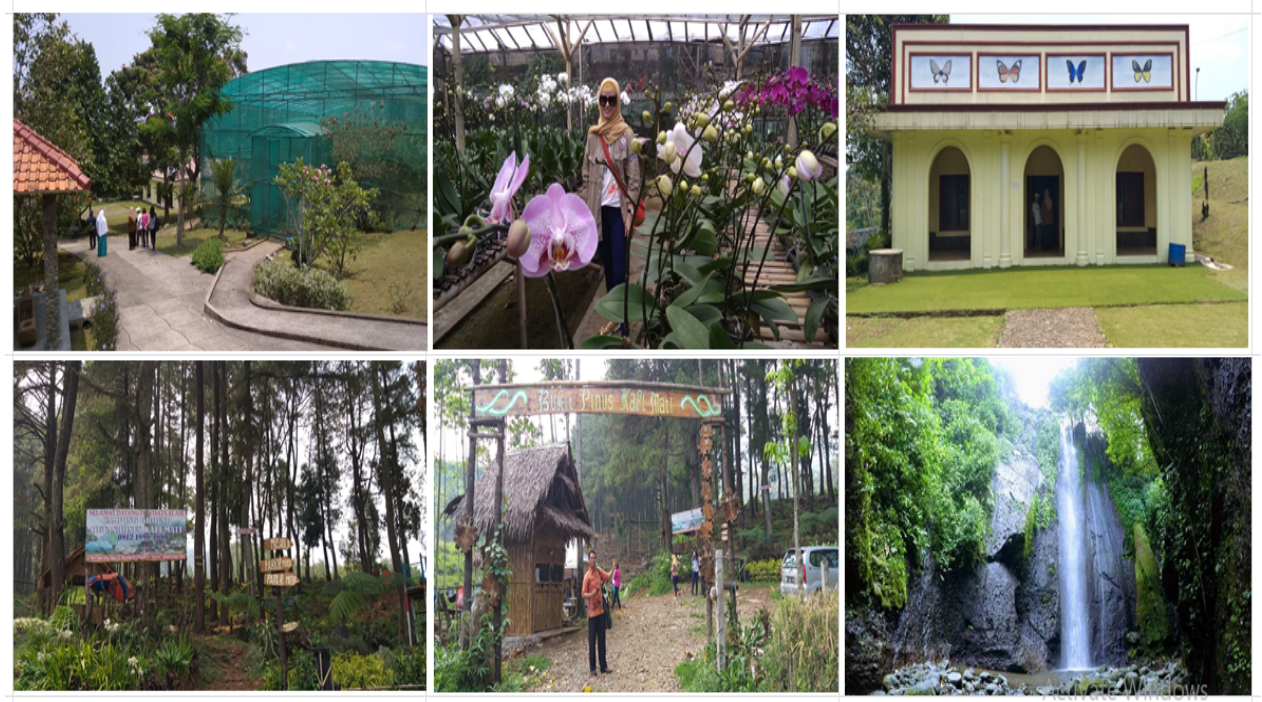

Lampiran 3.

Daftar Mahasiswa Pelaksana Kegiatan

\begin{tabular}{|c|l|c|c|}
\hline No & \multicolumn{1}{|c|}{ NAMA } & NIM & Peran \\
\hline 1 & Axel Reimonta & 419219001 & Panitia \\
\hline 2 & Devi Susilawati & 419119003 & Panitia \\
\hline 3 & Gian Wicaksono & 418119005 & Panitia \\
\hline 4 & Jody Renaldy Arifin & 419219002 & Panitia \\
\hline 5 & Larasati & 419219003 & Panitia \\
\hline 6 & Nadia Istiani Putri & 419219004 & Panitia \\
\hline 7 & Ni Luh Putu Vera Kasmayanti & 419119006 & Panitia \\
\hline 8 & Octovan Risky N & 419119007 & Panitia \\
\hline 9 & Putri Veronika Setiadi & 419119008 & Panitia \\
\hline 10 & Rafi Syahputra Pratama & 419119009 & Panitia \\
\hline 11 & Tiara Nada Saputra & 419119012 & Panitia \\
\hline 12 & Tria Ananda & 419219005 & Panitia \\
\hline 13 & Vira Rizki Vanika & 419119013 & Panitia \\
\hline
\end{tabular}

